Issue 2 (Oktober, 2017)

\title{
PENGARUH GAYA KEPEMIMPINAN DAN STRES KERJA TERHADAP KEPUASAN KERJA KARYAWAN
}

\author{
Hamsinah $^{1)}$, Herman Sjahruddin ${ }^{2)}$, Mustafa Gani3) \\ Ref.inha@yahoo.com \\ 1) Mahasiswa Program Studi Manajemen pada Sekolah Tinggi Ilmu Ekonomi Bongaya \\ Makassar \\ 2,3) Dosen Program Studi Manajemen pada Sekolah Tinggi Ilmu Ekonomi Bongaya \\ Makassar
}

\begin{abstract}
ABSTRAK
Penelitian ini bertujuan untuk menguji dan menganalisis pengaruh gaya kepemimpinan dan stres kerja terhadap kepuasan kerja karyawan pada PT. Utama Duta Harapan Makassar. Pengumpulan data menggunakan data primer yang di peroleh dari hasil penyebaran kuesioner. Populasi dalam penelitian ini adalah seluruh karyawan pada PT. Utama Duta Harapan Makassar yang berjumlah 110 orang karyawan tetap, Penentuan sampel dilakukan dengan menggunakan teknik stratified random sampling dengan menggunakan formulasi Slovin pada presisi sebesar $10 \%$ sehingga diperoleh jumlah sampel sebanyak 50 responden. Pengujian hipotesis dilakukan dengan menggunakan teknik Structural Equation Modelling (SEM) dengan bantuan software WarphPLS Ver.5.0. Hasil penelitian ini membuktikan bahwa gaya kepemimpinan yang ditunjukkan pimpinan berpengaruh positif dan signifikan terhadap kepuasan kerja, sedangkan pada pengujian pengaruh stress kerja terhadap kepuasan kerja ditemukan bahwa stress kerja yang di miliki karyawan tergolong rendah namun tidak memberikan pengaruh yang nyata terhadap peningkatan kepuasan kerja.
\end{abstract}

Kata kunci $\quad$ : Gaya Kepemimpinan, Stres Kerja, Kepuasan Kerja

ABSTRACT

This Study aimed to examine and analyze the interact Leadership Style and Work Stress of employees job satisfaction in PT. Utama Duta Harapan Makassar. Data collecting by using primary data obtained from the result questionnaires spread. Population in this study is all the employees in PT. Utama Duta Harapan Makassar amount 110 employees remain, samples stipulation using stratified random sampling by using Slovin formulation technic on $10 \%$ precision so that obtainable 50 respondents. Hypothesis testing using Structural Equation Modelling (SEM) technic with WarphPLS Ver.5.0. The result of this study prove that Leadership Style indicated by leader take positive effects and significant to Employess job satisfaction, while on testing the influence of work stress to job satisfaction found that work stress of employees is low but it is not giving the real effect to increase employees job satisfaction.

Keywords: $\quad$ Leadership style, work stress, employees job satisfaction 


\section{JURNAL ORGANISASI DAN MANAJEMEN}

Issue 2 (Oktober, 2017)

\section{Latar Belakang}

Tingginya intensitas persaingan yang dialami PT. Utama Duta Harapan dalam pemasaran produk elektronik seperti merek Miyako, Rinnai, dan Shimizu, mengakibatkan perusahaan perlu memperhatikan sumber daya manusianya melalui peningkatan kepuasan kerja karyawan. Pengelolaan sumber daya manusia dalam organisasi bukan hal yang mudah karena melibatkan berbagai elemen dalam sebuah organisasi, yaitu karyawan, pimpinan, maupun sistem itu sendiri.Perpaduan antara ketiga hal tersebut diharapkan mampu memunculkan kepuasan kerja karyawan.Kepuasan kerja mempunyai pengaruh yang cukup besar terhadap produktivitas organisasi baik secara langsung maupun tidak langsung.Kepuasan kerja merupakan suatu keadaann yang berkaitan dengan reaksi emosional dari persepsi seseorang yang telah mendapatkan kebutuhan dan permintaan yang diinginkannya dari pekerjaan yang dia lakukan . kepuasan kerja merupakan predikator kuat membangun komitmen karyawan diikuti dengan kepemimpinan (Soegihartono, 2012; dalam Pradifta, 2014).

Hasil pengamatan lapangan menunjukkan bahwa tingkat kepuasan kerja karyawan cenderung rendah, hal ini diperlihatkan melalui rendahnya disiplin kerja karyawan yang ditunjukkan dengan rendahnya kepatuhan karyawan pada aturan kerja, datang dan pulang tidak sesuai waktu kerja serta pemberian insentif yang tidak dilakukan secara adil. Kondisi tersebut, berdasarkan hasil wawancara dengan karyawan disebabkan karena pemimpin dalam melaksanakan tugas dan tanggung jawabnya memiliki kepedulian yang rendah kepada karyawan dan suasana kerja yang tidak kondusif (sering terjadi konflik antara karyawan bahkan dengan pimpinan). Faktor- faktor yang mempengaruhi kepuasan kerja (indikator) yaitu kesempatan untuk maju, keamanan kerja, gaji, pangkat, faktor instrinsik dari pekerjaan, kondisi kerja, aspek sosial dalam pekerjaan, fasilitas kesejahteraan. Pada penelitian ini, tinggi ataupun rendahnya kepuasan kerja karyawan disebabkan karena faktor instrinsik dari pekerjaan yang ditunjukkan melalui gaya kepemimpinan dan faktor kondisi kerja yang ditunjukkan dengan beban kerja yang berlebihan (stres kerja) (Sutrisno, 2009:83, dalam Tukimin, 2014).

Teori Keseimbangan (Equity Theory) yang dikemukakan Gibson, (1996); dalam Sinollah (2011) mengemukakan bahwa puas atau tidaknya karyawan merupakan hasil dari perbandingan antara input - outcome dirinya dengan input outcome karyawan lain (comparison person). Jadi jika perbandingan tersebut dirasakan seimbang (equity) maka karyawan tersebut akan merasa puas. Tetapi, apabila terjadi tidak seimbang dapat menyebabkan dua kemungkinan yaitu over compensation inequity (ketidak seimbangan yang menguntungkan dirinya) dan sebaliknya, under compensation inequity (ketidakseimbangan yang menguntungkan karyawan lain yang menjadi pembanding). Bahwa kepuasan kerja disebabkan karena adanya kesesuaian antara harapan dan kenyataan.Teori Keseimbangan (Equity Theory) seperti yang dikemukakan menjelaskan bahwa perasaan puas atau tidaknya karyawan ditentukan antara keseimbangan/kesesuaian antara harapan dan kenyataan (input - outcome) yang diperoleh karyawan dari pimpinan serta keseimbangan/kesesuaian antara harapan dan kenyataan (input - outcome) dari beban pekerjaan yang merupakan tugas dan tanggung jawab karyawan. Keseimbangan yang dimaksud dalam penelitian ini yaitu keseimbangan atau kesesuaian antara harapan dan kenyataan (input - outcome) dari gaya kepemimpinan dengan harapan dan kenyataan (input - outcome) dari pelaksanaan kerja (stress kerja). 


\section{JURNAL ORGANISASI DAN MANAJEMEN}

Issue 2 (Oktober, 2017)

Berdasarkan teori tersebut dapat dijelaskan bahwa peningkatan kepuasan kerja karyawan pada suatu organisasi tidak bisa dilepaskan dari peranan pemimpin dalam organisasi tersebut, serta jumlah (kuantitas) pekerjaan (beban kerja) yang jika diberikan secara proporsional akan mengakibatkan perasaan puas dari karyawan dalam bekerja yang kemudian menjadi kunci utama atau memainkan peran penting dan strategis dalam kelangsungan hidup suatu perusahaan. Gaya kepemimpinan ialah pola perilaku yang akan ditunjukkan oleh pemimpin dalam mempengaruhi orang lain atau karyawan. Pola perilaku tersebut dapat dipengaruhi oleh beberapa faktor seperti, seperti nilai-nilai, asumsi, persepsi, harapan maupun sikap yang ada dalam diri pemimpin (Ardana dkk, 2011: 181, dalam satyawati,dkk., 2014). Penelitian mengenai hubungan gaya kepemimpinan terhadap kepuasan kerja mengacu pada penelitian yang dilakukan Fitriansyah, dkk., (2013); Purnomo, dkk., (2011); Pradifta, dkk., (2014) bahwa gaya kepemimpinan transformasional dan transaksional berpengaruh positif dan signifikan terhadap kepuasan kerja, dan penelitian ini ditunjukkan pada penelitian Simanungkalit, dkk., (2013); Losiana lomanto, dkk., (2012); bahwa gaya kepemimpinan berpengaruh negatif dan signifikan terhadap kepuasan kerja.

Faktor lainnya yang mempengaruhi kepuasan kerja karyawan adalah stress kerja. Stres kerja merupakan istilah umum yang dapat diartikan sebagai tekanan hidup yang dirasakan terlalu sulit bagi seseorang. Stres akan terjadi jika seorang individu tidak mampu memahami keterbatasannya akan suatu hal. Ketidakmampuan ini nantinya akan menimbulkan rasa frustasi, gelisah, serta rasa bersalah yang merupakan awal dari permulaan stres tersebut. Stres kerja adalah suatu keadaan yang dialami individu dalam bekerja seperti, menghadapi sebuah peluang, kendala, atau tuntutan yang hasilnya dianggap tidak pasti namun penting (Robbins, 2007:793); dalam Noor, dkk., 2016). Pandangan lainnya menyatakan bahwa stres kerja adalah suatu kondisi ketegangan yang menciptakan adanya ketidakseimbangan fisik dan psikis, yang mempengaruhi emosi, proses berpikir dan kondisi seorang karyawan (Rivai, 2010:108; dalam Afrizal dkk., 2014). Penelitian mengenai hubungan stress kerja terhadap kepuasan kerja mengacu pada penelitian yang di lakukan Dhania, dkk., (2010); Dewi, dkk., (2015); Pratama, dkk., (2015); Bahwa stress kerja berpengaruh negative dan signifikan terhadap kepuasan kerja.

\section{Tinjauan Pustaka}

\section{Konsep Gaya Kepemimpinan}

Kepemimpinan secara harfian berasal dari kata pimpin. Kata pimpin mengandung pengertian mengarahkan, membina atau mengatur, menuntun dan juga menunjukkan ataupun mempengaruhi. Pemimpin mempunyai tanggung jawab baik secara fisik maupun spiritual terhadap keberhasilan aktivitas kerja dari yang dipimpin, sehingga menjadi pemimpin itu tidak mudah dan tidak akan setiap orang mempunyai kesamaan di dalam menjalankan ke-pemimpinannya. Kepemimpinan didefinisikan sebagai upaya mempengaruhi pengikut melalui proses komunikasi untuk mencapai tujuan tertentu. Definisi di atas menunjukkan bahwa kepemimpinan melibatkan penggunaan pengaruh. Unsur kedua, menyangkut pentingnya proses komunikasi, kejelasan dan ketepatan komunikasi mempengaruhi perilaku dan prestasi bawahan. Unsur terakhir yaitu pencapaian tujuan.Pemimpin yang efektif mungkin harus berurusan dengan tujuan individu, kelompok, dan organisasi. Para ahli biasanya memberikan definisi dengan cara yang bervariasi mengenai kepemimpinan. 


\section{JURNAL ORGANISASI DAN MANAJEMEN}

Issue 2 (Oktober, 2017)

Kepemimpinan adalah kegiatan untuk mempengaruhi orang lain atau seni untuk mempengaruhi perilaku manusia, baik secara perseorangan atau kelompok (Thoha, 2012:8). Pandangan lainnya mengemukakan bahwa kepemimpinan adalah kemampuan untuk mempengaruhi suatu kelompok untuk pencapaian suatu visi atau tujuan (Robbins, 2011:410), Kepemimpinan adalah proses mempengaruhi dalam menentukan tujuan organisasi, memotivasi perilaku pengikutnya untuk mencapai tujuan dan mempengaruhi kelompok dan budaya (Rivai, 2004:2). Berdasarkan pada definisi yang telah dikemukakan beberapa ahli, maka dapat disimpulkan bahwa kepemimpinan adalah penggunaan pengaruh bukan paksaan untuk memotivasi anggota organisasi serta memahami manfaat kerja bersama orang lain dan dapat mengartikulasikan visi, mewujudkan nilai dan menciptakan lingkungan untuk mencapai tujuan yang telah ditetapkan. Selain itu kepemimpinan dapat menyatu dan menstimulus serta memotivasi pengikutnya guna mencapai sesuatu yang telah ditargetkan. Setiap pemimpin mempunyai gaya kepemimpinan yang berbeda antara satu dengan lainnya, dan tidak mesti suatu gaya kepemimpinan lebih baik atau lebih buruk daripada gaya kepemimpinan lainnya.

\section{Gaya Kepemimpinan}

Gaya seseorang dalam memimpin, membimbing dan mempengaruhi atau mengontrol pikiran, perasaan atau tingkah laku orang lain dimaksudkan dalam rangka mencapai suatu tujuan tertentu. Menurut Hasibuan (2007:70) gaya kepemimpinan adalah suatu cara pemimpin untuk mempengaruhi bawahannya, agar mau bekerja sama secara produktif untuk mencapai tujuan organisasi. Sedangkan menurut Suwatno dan Priansa (2011:155) : "Gaya kepemimpinan yaitu perilaku yang disukai oleh pemimpin dalam proses mengarahkan dan mempengaruhi pengikut “.Dan Menurut Tjiptono (2006:161) gaya kepemimpinan adalah suatu cara yang digunakan pemimpin dalam berinteraksi dengan bawahannya. Sementara itu, pendapat lain menyebutkan bahwa gaya kepemimpinan adalah pola tingkah laku (kata-kata dan tindakan-tindakan) dari seorang pemimpin yang dirasakan oleh orang lain (Hersey, 2004:29).

\section{Gaya Kepemimpinan Transformasional}

Kepemimpinan transformasional menunjuk pada proses membangun komitmen terhadap sasaran organisasi dan memberi kepercayaan kepada para pengikut untuk mencapai sasaran-sasaran tersebut. Teori transformasional mempelajari juga bagaimana para pemimpin mengubah budaya dan struktur organisasi agar lebih konsisten dengan strategi-strategi manajemen untuk mencapai sasaran organisasional. Kepemimpinan transformasional merupakan kemampuan pemimpin mengubah lingkungan kerja, motivasi kerja, dan pola kerja, dan nilai-nilai kerja yang dipersepsikan bawahan sehingga mereka lebih mampu mengoptimalkan kinerja untuk mencapai tujuan organisasi. Berarti, sebuah proses transformasional terjadi dalam hubungan kepemimpinan manakala pemimpin membangun kesadaran bawahan akan pentingnya nilai kerja, memperluas dan meningkatkan kebutuhan melampaui minat pribadi serta mendorong perubahan tersebut ke arah kepentingan bersama termasuk kepentingan organisasi (Bass dan Avolio, 2003).

Pemimpin transformasional harus mempunyai kemampuan untuk menyamakan visi masa depan dengan bawahannya, serta mempertinggi kebutuhan bawahan pada tingkat yang lebih tinggi dari pada apa yang mereka butuhkan. pemimpin transformasional harus mampu membujuk para bawahannya 


\section{JURNAL ORGANISASI DAN MANAJEMEN}

Issue 2 (Oktober, 2017)

melaksanakan tugas mereka melebihi kepentingan mereka sendiri demi kepentingan organisasi yang lebih besar. Pengembangan konsep kepemimpinan (transformasional dan transaksional) dengan berlandaskan pada pendapat Maslow mengenai hierarki kebutuhan manusia. Keterkaitan tersebut dapat dipahami dengan gagasan bahwa kebutuhan karyawan yang lebih rendah, seperti kebutuhan fisiologis dan rasa aman hanya dapat dipenuhi melalui praktek gaya kepemimpinan transaksional (Bass dan Avolio (2003). Sejauhmana pemimpin dikatakan sebagai pemimpin transformasional, dapat diukur dalam hubungan dengan pengaruh pemimpin tersebut berhadapan karyawan. Oleh karena itu, Bass \& Avolio (2003), mengemukakan ada tiga cara seorang pemimpin transformasional memotivasi karyawannya, yaitu dengan: (1) mendorong karyawan untuk lebih menyadari arti penting hasil usaha, (2) mendorong karyawan untuk mendahulukan kepentingan kelompok, (3) meningkatkan kebutuhan karyawan yang tinggi seperti harga diri dan aktualisasi diri.

Dengan cara demikian, antara pimpinan dan bawahan terjadi kesamaan persepsi sehingga mereka dapat mengoptimalkan usaha ke arah tujuan yang ingin dicapai organisasi. Melalui cara ini, diharapkan akan tumbuh kepercayaan, kebanggaan, komitmen, rasa hormat, dan loyal kepada atasan sehingga mereka mampu mengoptimalkan usaha dan kinerja mereka lebih baik dari biasanya. Ringkasnya, pemimpin transformasional berupaya melakukan transforming of visionary menjadi visi bersama sehingga mereka (bawahan plus pemimpin) bekerja untuk mewujudkan visi menjadi kenyataan.

\section{Gaya Kepemimpinan Transaksional}

Kepemimpinan transaksional merupakan salah satu gaya kepemimpinan yang intinya menekankan transaksi di antara pemimpin dan bawahan. Kepemimpinan transaksional memungkinkan pemimpin memotivasi dan mempengaruhi bawahan dengan cara mempertukarkan reward dengan kinerja tertentu. Artinya, dalam sebuah transaksi bawahan dijanjikan untuk diberi reward bila bawahan mampu menyelesaikan tugasnya sesuai dengan kesepakatan yang telah dibuat bersama Mustopadidjaja, (2008).Argumentasi terhadapreward mendorong Bass \& Avolio (2003) untuk mendefinisikan kepemimpinan transaksional sebagai bentuk hubungan yang mempertukarkan jabatan atau tugas tertentu jika bawahan mampu menyelesaikan dengan baik tugas tersebut.

Bass dan Avolio (2003) yang mengemukakan bahwa hubungan pemimpin transaksional dengan karyawan tercermin dari tiga hal yakni: (1) pemimpin mengetahui apa yang diinginkan karyawan dan menjelaskan apa yang akan mereka dapatkan apabila kerjanya sesuai dengan harapan; (2) pemimpin menukar usahausaha yang dilakukan oleh karyawan dengan imbalan, (3) Pemimpin responsif terhadap kepentingan pribadi karyawan selama kepentingan tersebut sebanding dengan nilai pekerjaan yang telah dilakukan karyawan.

\section{Konsep Stres Kerja}

Tinggi rendahnya kinerja karyawan sangat dipengaruhi tingkat stres yang dimiliki karyawan tersebut.Stres kerjamerupakan suatu kondisi ketegangan yang mempengaruhi emosi, proses berpikir dan kondisi seseorang, tingkat stres yang tinggi dapat mempengaruhi kemampuan seseorang untuk menghadapi lingkungan kerjanya dan padaakhirnya mengganggu pelaksanaan tugas-tugasnya sehingga berdampak negatif terhadap prestasi kerjanya atau kinerjanya (Handoko, 2008). 


\section{JURNAL ORGANISASI DAN MANAJEMEN}

Issue 2 (Oktober, 2017)

Stres adalah kondisi ketegangan yang mempengaruhi emosi, proses berpikir sehingga menjadi gugup, merasakan kekhawatiran kronis, mudah marah, agresif dan tidak dapat rileks (Hasibuan, 2003:203). Pendapat lain menyatakan bahwa stres kerja terjadi jika seseorang tidak dapat memenuhi tuntutan atau kebutuhan dari pekerjaannya (Losyik, 2007:4). Pendapat selanjutnya Stress menurut robbins (2007:793) adalah suatu keadaan yang dialami oleh individu dalam menghadapi sebuah peluang, kendala, atau tuntutan yang hasilnya dianggap tidak pasti namun penting.

Individu pada umumnya menganggap bahwa stres merupakan suatu kondisi yang mengarah kepada timbulnya penyakit fisik maupun mental atau mengarah ke perilaku yang tidak wajar (distress).Akibat lain yang ditimbulkan stres yang bersifat positif disebut sebagai eustress yang merupakan kekuatan yang positif dimana stres kadangkala dapat diperlukan untuk menghasilkan prestasi yang tinggi.(Selye, 1976; dalam Munandar, 2008:378) Cerminan dalam mengetahui tingkat stres yang dialami individu (karyawan) dalam bekerja dapat dilihat berdasarkan pada beberapa(Rahmawati, 2009, dalam Dewi dan Suwandana, 2016)adalah : (1) Tuntutan tugas; pada umumnya karyawan berpendapat bahwa pekerjaan yang dilakukan melebihi kapasitas waktu yang dimiliki sehingga karyawan merasa dikejar waktu dalam menyelesaikan pekerjaan, (2) Tuntutan peran, pada umumnya karyawan berpendapat bahwa peraturan yang cukup fleksibel dalam menjalankan tugas akan turut mendukung karyawan selama bekerja sehingga konflik peran yang dirasakan dari tugas yang dibebankan oleh atasan masih dapat diatasi, (3) tuntutan hubungan antarpribadi, pada umumnya karyawan berpendapat bahwa konflik yang terjadi dengan rekan kerja hanya sebatas pada permasalahan yang berkaitan dengan pekerjaan bukan karena permasalahan pribadi sehingga hubungan yang baik antar karyawan tetap terjaga, (4) Struktur organisasi, pada umumnya karyawan berpendapat bahwa struktur organisasi yang jelas akan menggambarkan alur komunikasi yang jelas sehingga karyawan mengetahui dari mana informasi diperoleh untuk menjalankan pekerjaannya, (5) Kepemimpinan organisasi, pada umumnya, karyawan berpendapat bahwa atasan memberikan pekerjaan berdasarkan deskripsi pekerjaan yang sudah ditetapkan, (6) Tahap hidup organisasi, perusahaan yang berada pada tahap mapan dan sedang melakukan pengembangan, pada umumnya karyawan akan berusaha bekerja keras menghadapi berbagai tuntutan tugas sebab pemberhentian karyawan menjadi pemicu kecemasannya.

\section{Konsep kepuasan kerja}

Kepuasan kerja pada dasarnya merupakan sesuatu yang bersifat individual.Setiap individu memiliki tingkat kepuasan yang berbeda-beda sesuai dengan sistem nilai yang berlaku pada dirinya.Makin tinggi penilaian terhadap kegiatan dirasakan sesuai dengan keinginan individu, maka makin tinggi kepuasannya terhadap kegiatan tersebut.Jadi, secara garis besar kepuasan kerja dapat diartikan sebagai hal yang menyenangkan atau yang tidak menyenangkan yang mana pegawai memandang pekerjannya. Kepuasan kerja didefinisikan sebagai keadaan yang menyenangkan atau emosi positif yang dihasilkan dari penilaian pekerjaan atau pengalaman kerja seseorang.Kepuasan kerja dihasilkan dari persepsi karyawan mengenai seberapa baik pekerjaan mereka menyediakan hal yang dipandang penting. 


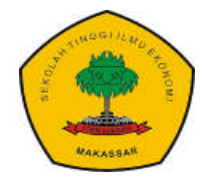

\section{JURNAL ORGANISASI DAN MANAJEMEN}

Issue 2 (Oktober, 2017)

Terdapat Lima aspek kepuasan kerja diukur dengan Job Descriptive Index(JDI), (Luthans, 2006, dalam Prabowo, 2016).yaitu; (1) Pekerjaan itu sendiri, dalam hal ini dimana perusahaan memberikan tugas yang menarik, tantangan dalam pekerjaan, tanggung jawab terhadap pekerjaan dan karakteristik pekerjaan serta kompleksitas pekerjaan menghubungkan antara kepribadian dengan kepuasan kerja, (2) Gaji, pemberian gaji yang sesuai dengan kontribusi karyawan, ketepatan waktu dalam pembayaran gaji, dan sistem pemberian gaji di dalam perusahaan merupakan salah satu faktor penentu kepuasan kerja karyawan, (3) Promosi, yaitu kesempatan untuk maju dalam organisasi merupakan salah satu penentu kepuasan kerja, (4) pengawasan, yaitu kemampuan penyedia untuk memberikan bantuan teknis dan dukungan perilaku serta hubungan yang baik akan menjadi faktor penentu kepuasan kerja karyawan dalam perusahaan, (5) Rekan kerja, yaitu rekan kerja yang kooperatif merupakan sumber kepuasan kerja yang paling sederhana pada karyawan secara individu terutama rekan kerja yang bertindak sebagai sumber dukungan, kenyamanan dan nasihat.

\section{Metode Penelitian}

Penelitian ini termasuk penelitian metode deskriptif kuantitatif yang bertujuan untuk menjelaskan suatu fenomena empiris yang disertai data statistik dan pola hubungan antara variabel. Pada penelitian ini variabel terikat kepuasan kerja $(\mathrm{Y})$ dipengaruhi oleh variabel bebas gaya kepemimpinan $\left(\mathrm{X}_{1}\right)$ dan stress kerja $\left(\mathrm{X}_{2}\right)$. Penentuan sampel dilakukan dengan menggunakan teknik stratified random sampling dengan menggunakan formulasi Slovin pada presisi sebesar $10 \%$ sehingga diperoleh jumlah sampel sebanyak 50 responden. Penelitian ini menggunakan analisis SEM (Structural equation modeling) dibantu dengan WaphPLS Ver. 5.0.

\section{Hasil Penelitian}

\section{Evaluasi model pengukuran (Validitas Konvergen)}

Convergent validity dari model pengukuran dapat dilihat dari korelasi antara skor indikator dengan skor konstruknya (loading factor) dengan kriteria nilai loading factor dari setiap indikator lebih besar dari 0,70 dapat dikatakan valid. Selanjutnya untuk nilai p-value apabila $<0,05$ dianggap signifikan. Pada beberapa kasus, syarat loading di atas 0,70 sering tidak terpenuhi khususnya untuk kuesioner yang baru dikembangkan. Oleh karena itu,loading antara 0,40-0,70 harus tetap dipertimbangkan untuk dipertahankan. Selanjutnya dijelaskan pula bahwa, indikator dengan loading $<$ 0,40 dihapus dari model. Penghapusan indikator dengan loading antara 0,40-0,70 dilakukan apabila indikator tersebut dapat meningkatkan AVE dan composite reliability diatas nilai batasannya. Nilai batasan untuk AVE 0,50 dan composite reliability adalah 0,50 ((Machfud dan Dwi, 2013: 66 dalam Arista, 2015). Hasil pengolahan Convergent Validity dapat dilihat pada tabel berikut ini:

Tabel 1 Hasil output combined loadings and cross-loading

\begin{tabular}{|c|r|r|r|r|c|}
\hline Model 1 & KPMN & STRS KRJ & \multicolumn{1}{c|}{ KPSN } & \multicolumn{1}{c|}{ SE } & P value \\
\hline $\mathrm{X}_{11}$ & 0.922 & -0.110 & -0.062 & 0.099 & $<0.001$ \\
\hline $\mathrm{X}_{12}$ & 0.922 & 0.110 & 0.062 & 0.099 & $<0.001$ \\
\hline $\mathrm{X}_{21}$ & -0.11 & -0.439 & -0.168 & 0.119 & $<0.001$ \\
\hline $\mathrm{X}_{22}$ & 0.121 & 0.935 & -0.031 & 0.099 & $<0.001$ \\
\hline $\mathrm{X}_{23}$ & 0.121 & 0.935 & -0.031 & 0.099 & $<0.001$ \\
\hline $\mathrm{X}_{24}$ & -0.165 & 0.789 & -0.06 & 0.104 & $<0.001$ \\
\hline
\end{tabular}


Issue 2 (Oktober, 2017)

\begin{tabular}{|l|r|r|r|r|r|}
$\mathrm{X}_{25}$ & 0.086 & 0.926 & 0.014 & 0.099 & $<0.001$ \\
\hline $\mathrm{X}_{26}$ & -0.245 & 0.919 & 0.02 & 0.099 & $<0.001$ \\
\hline $\mathrm{Y}_{11}$ & 0.467 & 0 & 0.843 & 0.102 & $<0.001$ \\
\hline $\mathrm{Y}_{12}$ & -0.322 & -0.082 & 0.759 & 0.106 & $<0.001$ \\
\hline $\mathrm{Y}_{13}$ & -0.958 & 0.008 & 0.543 & 0.115 & $<0.001$ \\
\hline $\mathrm{Y}_{14}$ & 0.482 & -0.022 & 0.852 & 0.102 & $<0.001$ \\
\hline $\mathrm{Y}_{15}$ & -0.053 & 0.104 & 0.737 & 0.107 & $<0.001$ \\
\hline
\end{tabular}

Berdasarkan hasil pengolahan data diatas maka dapat dijelaskan sebagai berikut : Pada model 1 diatas, hasil pengolahan data tersebut menjelaskan bahwa dari 2 dimensi gaya kepemimpinan, yaitu $\mathrm{X}_{11}, \mathrm{X}_{12}$, kedua dimensi tersebut memenuhi standar Convergent Validity dengan nilai $>0.70$ dan $P$-value juga telah memenuhi syarat yaitu memiliki nilai sebesar $<0,001(<0,05)$. Untuk stres kerja menunjukkan bahwa terdapat 1 indikator yang tidak memenuhi standar Convergent Validity yaitu $\mathrm{X}_{21}<0.70$,sehingga terdapat alasan yang cukup kuat untuk mengeluarkannya dari model dan kemudian melanjutkannya dengan model 2. Mengacu pada 5 indikator kepuasan kerja, yaitu $\mathrm{Y}_{11}, \mathrm{Y}_{12}, \mathrm{Y}_{13}, \mathrm{Y}_{14}, \mathrm{Y}_{15}$. dari ke 5 indikator terdapat 1 indikator yang tidak memenuhi standar Convergent Validity yaitu $\mathrm{Y}_{13}$ dengan nilai $<0.70$,sehingga indikator tersebut harus di keluarkan dari model.Berdasarkan hasil tersebut (Tabel 4.6) ditemukan bahwa masih terdapat indikator dari variabel kepuasan kerja (Y)yang tidak memenuhi standar Convergent validity(uji validitas) yaitu, $Y_{13}$ dengan nilai sebesar $0,543<0.70$, sehingga terdapat alasan yang cukup kuat untuk mengeluarkannya dari model dan kemudian melanjutkannya dengan model 2.

\section{Uji Composite reliability (uji reliabilitas kontruk)}

Penelitian ini menggunakan tiga variabel laten (variabel yang tidak terukur) yaitu variabel gaya kepemimpinan $\left(\mathrm{X}_{1}\right)$ dan stress kerja $\left(\mathrm{X}_{2}\right)$ serta kepuasan kerja (Y). Suatu variabel yang dipandang mampu (handal) dalam menjelaskan data dari variabel tersebut, pengujiannya dapat dilihat pada nilai composite reliability dan Cronbach's Alpha> 0,60, untuk itu dapat diperlihatkan pada tabel berikut:

Tabel 2 Latent variable coefficients (composite reliability) (model 1)

\begin{tabular}{|c|c|c|c|}
\hline MODEL 1 & GP & S KRJ & KPS \\
\hline R-Squared & & & 0.454 \\
\hline Composite reliab. & 0.919 & 0.905 & 0.866 \\
\hline Cronbach's Alpha & 0.823 & 0.807 & 0.805 \\
\hline Avg. Var. Extrac. & 0.850 & 0.711 & 0.570 \\
\hline Full Collin. VIF & 1.843 & 1.042 & 1.789 \\
\hline Q-Squared & & & 0.518 \\
\hline
\end{tabular}

Nilai composite reliability untuk variabel gaya kepemimpinan sebesar 0,919> 0,60 sedangkan untuk variabel stress kerja sebesar 0,905>0,60 dan yang terakhir pada variabel kepuasan kerja sebesar 0,866>0,60. Selanjutnya untuk Cronbach's Alpha pada variabel gaya kepemimpinan sebesar 0,823>0,60 sedangkan untuk variabel stress kerja sebesar 0,807>0,60 dan yang terakhir pada variabel kepuasan kerja sebesar 0,805> 0,60. Untuk nilai Average Variances Extracted (AVE)nilai variasi rata-rata pada variabel gaya kepemmpinan sebesar $0,850>0,50$ sedangkan untuk variabel stress kerja sebesar $0,711<0,50$ dan yang terakhir pada variabel kepuasan kerja sebesar 0,570>0,50. Berdasarkan hasil tersebut maka nilai yang 


\section{JURNAL ORGANISASI DAN MANAJEMEN}

Issue 2 (Oktober, 2017)

belum memenuhi kriteria pengujian ditemukan pada nilai variasi rata-rata (AVE) untuk variabelkepuasan kerja, sehingga terdapat cukup alasan yang kuat untuk mengujinya kembali pada model 2 .

\section{Evaluasi Model Struktural Pengukuran (Outer Model) Model 2}

Pengolahan selanjutnya pada model 2 yaitu evaluasi outer model dilakukan melalui 3 kriteria yaitu convergent validity, discriminant validity dan composite reliability. Berikut ini adalah hasil pengolahan data:

\subsection{Convergent Validity (Validitas Konvergen)}

Convergent validity dari model pengukuran dapat dilihat dari korelasi antara skor indikator dengan skor konstruknya (loading factor) dengan kriteria nilai loading factordari setiap indikator lebih besar dari 0,70 dapat dikatakan valid. Selanjutnya untuk nilai p-value apabila $<0,05$ dianggap signifikan. Pada beberapa kasus, syarat loading di atas 0,70 sering tidak terpenuhi khususnya untuk kuesioner yang baru dikembangkan. Oleh karena itu, loading antara 0,40-0,70 harus tetap dipertimbangkan untuk dipertahankan. Selanjutnya dijelaskan pula bahwa, indikator dengan loading $<$ 0,40 dihapus dari model. Penghapusan indikator dengan loading antara 0,40-0,70 dilakukan apabila indikator tersebut dapat meningkatkan AVE dan composite reliability diatas nilai batasannya. Nilai batasan untuk AVE 0,50 dan composite reliability adalah 0,50 (Machfud dan Dwi, 2013: 66 dalam Arista, 2015)

Tabel 3 Hasil output combined loadings and cross-loading

\begin{tabular}{|c|c|c|c|c|c|}
\hline Model 2 & KPMN & STRS KRJ & KPSN & SE & P value \\
\hline $\mathrm{X}_{11}$ & 0.922 & -0.097 & -0.136 & 0.099 & $<0.001$ \\
\hline $\mathrm{X}_{12}$ & 0.922 & 0.097 & 0.136 & 0.099 & $<0.001$ \\
\hline $\mathrm{X}_{22}$ & 0.037 & 0.946 & 0.086 & 0.098 & $<0.001$ \\
\hline $\mathrm{X}_{23}$ & 0.037 & 0.946 & 0.086 & 0.098 & $<0.001$ \\
\hline $\mathrm{X}_{24}$ & 0.026 & 0.791 & -0.226 & 0.104 & $<0.001$ \\
\hline $\mathrm{X}_{25}$ & 0.06 & 0.917 & 0.059 & 0.099 & $<0.001$ \\
\hline $\mathrm{X}_{26}$ & -0.157 & 0.926 & -0.041 & 0.099 & $<0.001$ \\
\hline $\mathrm{Y}_{11}$ & 0.086 & -0.022 & 0.912 & 0.100 & $<0.001$ \\
\hline $\mathrm{Y}_{12}$ & -0.054 & -0.024 & 0.667 & 0.109 & $<0.001$ \\
\hline $\mathrm{Y}_{14}$ & 0.175 & -0.033 & 0.912 & 0.100 & $<0.001$ \\
\hline $\mathrm{Y}_{15}$ & -0.275 & 0.09 & 0.735 & 0.107 & $<0.001$ \\
\hline
\end{tabular}

Hasil pada tabel diatas, menunjukkan hasil pengujian Convergent validity untuk model 2, dimana pada model 1 sebelumnya terdapat beberapa indikator pada variabel stress kerja dan kepuasan kerja yang tidak memenuhi standar Convergent validitysehingga dilakukan pengujian model 2. Pada pengujian model 2 diatas, semua indikator yang tidak memenuhi standar Convergent validity telah dikeluarkan dari model, sehingga pengujian Convergent validity pada model 2 telah memenuhi standar Convergent Validity dengan nilai $>0.70$ dan $P$-value juga telah memenuhi syarat yaitu memiliki nilai sebesar $<0,001(<0,05)$ untuk seluruh indikator dari variabel stress kerja dan kepuasan kerja.

\subsection{Uji Composite reliability (uji realibilitas kontruk)}




\section{JURNAL ORGANISASI DAN MANAJEMEN}

Issue 2 (Oktober, 2017)

Penelitian ini menggunakan tiga variabel laten (variabel yang tidak terukur) yaitu variabel gaya kepemimpinan $\left(\mathrm{X}_{1}\right)$ dan stres kerja $\left(\mathrm{X}_{2}\right)$ serta kepuasan kerja $(\mathrm{Y})$. Suatu variabel yang dipandang mampu (handal) dalam menjelaskan data dari variabel tersebut, pengujiannya dapat dilihat pada nilai composite reliability dan Cronbach's Alpha<0,60, untuk itu dapat diperlihatkan pada tabel berikut:

Tabel 4 Hasil output latent variable coefficients (model 2)

\begin{tabular}{|c|c|c|c|}
\hline MODEL 2 & GP & S KRJ & KPS \\
\hline R-Squared & & & 0.595 \\
\hline Composite reliab. & 0.919 & 0.958 & 0.885 \\
\hline Cronbach's Alpha & 0.823 & 0.945 & 0.823 \\
\hline Avg. Var. Extrac. & 0.850 & 0.822 & 0.662 \\
\hline Full Collin. VIF & 2.128 & 1.048 & 2.076 \\
\hline Q-Squared & & & 0.591 \\
\hline
\end{tabular}

Nilai composite reliability untuk variabel gaya kepemimpinan sebesar 0,919> 0,60 sedangkan untuk variabel stres kerja sebesar 0,958>0,60 dan yang terakhir pada variabel kepuasan kerja sebesar 0,885>0,60. Selanjutnya untuk Cronbach's Alpha pada variabel gaya kepemimpinan sebesar 0,823>0,60 sedangkan untuk variabel stres kerja sebesar 0,945> 0,60 dan yang terakhir pada variabel kepuasan kerja sebesar 0,823>0,60. Untuk nilai Average Variances Extracted (AVE)/ nilai variasi rata-rata pada variabel gaya kepemimpinan sebesar $0,850>0,50$ sedangkan untuk variabel stress kerja sebesar $0,822<0,50$ dan yang terakhir pada variabel kepuasan kerja sebesar 0,662>0,50.

Berdasarkan hasil tersebut maka keseluruhan nilai memenuhi kriteria pengujian, sehingga terdapat cukup alasan yang kuat untuk mengujinya kembali pada model 2 dan memiliki alasan yang kuat untuk dianalisis lebih lanjut dimodel 2.

Tabel 5 Nilai AVE (Average Variance Extracted)

\begin{tabular}{|l|l|l|}
\hline Variabel Laten & Nilai AVE & Kriteria \\
\hline GP & 0,850 & $>0,50$ \\
\hline SK & 0,822 & $>0,50$ \\
\hline KP & 0,662 & $>0,50$ \\
\hline
\end{tabular}

Berdasarkan hasil tersebut ketiga konstruk telah memenuhi convergent validity.Gaya kepemimpinan dengan nilai $0,850>0,50$, Stress kerja dengan nilai 0,822 juga telah memenuhi nilai $>0,50$ dan Kepuasan kerja memiliki nilai 0,662> 0,50. Kesimpulannya keseluruhan variabel telah memenuhi kriteria convergent validity.

\subsection{Discriminant Validity (Validitas Diskriminan)}

Discriminant validity dinilai dari cross loading pengukuran dengan konstruk. Dapat dilihat dengan melihat loading konstruk laten, yang akan memprediksi indikatornya lebih baik daripada konstruk lainnya. Jika korelasi konstruk dengan pokok pengukuran (setiap indikator) lebih besar daripada ukuran konstruk lainnya maka validitas diskriminan terpenuhi. 
Issue 2 (Oktober, 2017)

Tabel 6 Nilai loading konstruk laten indikator ke konstruk lainnya

\begin{tabular}{|l|l|l|l|l|}
\hline \multirow{2}{*}{ Indikator } & \multirow{2}{*}{ Loading } & \multicolumn{2}{c|}{ Nilai Loading ke konstruk lainnya } \\
\cline { 3 - 5 } & & \multicolumn{1}{|c|}{ GP } & \multicolumn{1}{c|}{ SK } \\
\hline$X_{11}$ & $(0.922)$ & & -0.097 & -0.136 \\
\hline$X_{12}$ & $(0.922)$ & & 0.097 & 0.136 \\
\hline$X_{22}$ & $(0.946)$ & 0.037 & & 0.086 \\
\hline$X_{23}$ & $(0.946)$ & 0.037 & & 0.086 \\
\hline$X_{24}$ & $(0.791)$ & 0.026 & & -0.226 \\
\hline$X_{25}$ & $(0.917)$ & 0.06 & & 0.059 \\
\hline$X_{26}$ & $(0.926)$ & -0.157 & & -0.041 \\
\hline$Y_{11}$ & $(0.912)$ & 0.086 & -0.022 & \\
\hline$Y_{12}$ & $(0.667)$ & -0.054 & -0.024 & \\
\hline$Y_{14}$ & $(0.912)$ & 0.175 & -0.033 & \\
\hline$Y_{15}$ & $(0.735)$ & -0.275 & 0.09 & \\
\hline
\end{tabular}

Keseluruhan indikator telah memenuhi kriteria validitas diskriminan.Variabel gaya kepemimpinan yang memiliki 2 dimensi yang dilambangkan dengan $\mathrm{X}_{11}, \mathrm{X}_{12}$. Untuk dimensi $\mathrm{X}_{11}$ memiliki nilai loading 0,922 yang nilai loading-nya lebih besar dari loading ke konstruk lain yaitu -0,097 dan -0,136 dan begitu juga untuk dimensi $\mathrm{X}_{12}$ memiliki nilai loading yang lebih besar dari nilai loading ke konstruk lain. Variabel stress kerja memiliki 5 indikator yang dilambangkan dengan $\mathrm{X}_{22}, \mathrm{X}_{23}, \mathrm{X}_{24}$ dan $\mathrm{X}_{25}, \mathrm{X}_{26}$. Untuk indikator $\mathrm{X}_{22}$ memiliki nilai loading 0,946 yang nilai loading-nya lebih besar dari loading ke konstruk lain yaitu 0,037 dan -0,086 dan ke 4 indikator stress kerja lainnya juga memiliki nilai loading yang lebih besar dari nilai loading ke konstruk lain.

\section{Evaluasi Model Struktural (Inner ModeI)}

Tahap selanjutnya adalah melakukan evaluasi struktural (inner model) yang meliputi uji kecocokan model (model fit), path coefficient, dan $\mathrm{R}^{2}$. Pada uji kecocokan model terdapat 3 indeks pengujian, yaitu average path coefficient (APC), average $R$ squared (ARS) dan average varians factor (AVIF) dengan kriteria APC dan ARS diterima dengan syarat $p-$ value $<$ 0,05 dan AVIF lebih kecil dari 5 (Mahfud Sholihin dan Dwi Ratmono, 2013: 61).

Tabel 7 Hasil output model fit indices

\begin{tabular}{|l|l|l|l|}
\hline & \multicolumn{1}{|c|}{ Indeks } & \multicolumn{1}{|c|}{ P-Value } & \multicolumn{1}{|c|}{ Kriteria } \\
\hline APC & 0,392 & $\mathrm{P}<0,001$ & $\mathrm{P}<0,05$ \\
\hline ARS & 0,595 & $\mathrm{P}<0,001$ & $\mathrm{P}<0,05$ \\
\hline AVIF & 1,054 Acceptable if $<5$ & & $\mathrm{AVIF}<5$ \\
\hline
\end{tabular}

Hasil output di atas, menjelaskan bahwa APC memiliki indeks sebesar 0,392 dengan nilai $p$-value $<0,001$. Sedangkan ARS memiliki indeks sebesar 0,595 dengan $p$ - value $<0,001$.Berdasarkan kriteria, APC sudah memenuhi kriteria karena memiliki nilai $\mathrm{p}<0,001$.Begitu pula dengan nilai $\mathrm{p}$ dari ARS yaitu $\mathrm{p}<0,001$.Nilai AVIF yang harus $<5$ sudah terpenuhi karena berdasarkan data tersebut AVIF nilainya 1,054.Dengan demikian, maka inner model dapat diterima.

\section{Hasil Uji Hipotesis}


Hasil korelasi antar konstruk diukur dengan melihat path coefficients dan tingkat signifikansinya yang kemudian dibandingkan dengan hipotesis penelitian yang terdapat di bab dua. Tingkat signifikansi yang dipakai dalam penelitian ini adalah sebesar 5\%. Berikut ini hipotesis yang dimaksudkan untuk membuktikan kebenaran dugaan penelitian yang terdiri dari tiga hipotesis, yaitu:

$\mathrm{H}_{1}$ = Gaya Kepemimpinan berpengaruh positif dan signifikan terhadap kepuasan kerja Pada PT. Utama Duta Harapan Makassar.

$\mathrm{H}_{2}=$ Stres kerja berpengaruh negatif dan signifikan terhadap kepuasan kerja Pada PT. Utama Duta Harapan Makassar.

$\mathrm{H}_{3}=$ Gaya Kepemimpinan merupakan variabel yang dominan pengaruhnya terhadap kepuasan kerja Pada PT. Utama Duta Harapan Makassar.

\section{Gambar 1 Hasil penelitian}

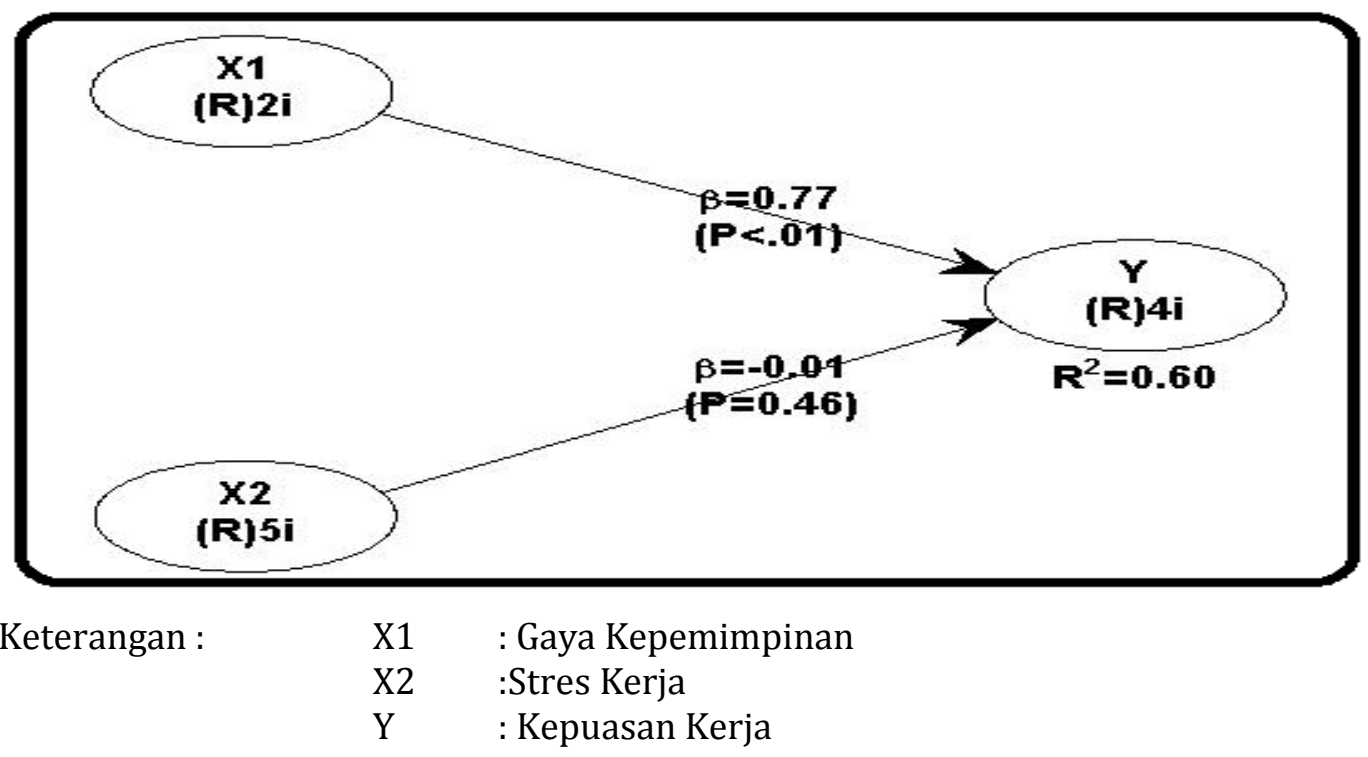

Tabel 8 Direct Effects

\begin{tabular}{|l|l|l|l|l|}
\hline Kriteria & Variabel & GP & SK & KP \\
\hline \multirow{4}{*}{ Path coefficients } & GP & - & - & - \\
\cline { 2 - 6 } & SK & - & - & - \\
\cline { 2 - 6 } & KP & 0,772 & $-0,012$ & - \\
\hline \multirow{5}{*}{-values } & GP & - & - & - \\
\cline { 2 - 6 } & $\mathbf{S K}$ & - & - & - \\
\cline { 2 - 6 } & $\mathbf{K P}$ & $<0,001$ & 0,465 & - \\
\hline \multirow{3}{*}{ Efect size for path } & $\mathbf{G P}$ & - & - & - \\
\cline { 2 - 6 } & $\mathbf{S K}$ & - & - & - \\
\cline { 2 - 5 } & $\mathbf{K P}$ & 0,593 & 0,002 & - \\
\hline
\end{tabular}

Hasil output di atas, menjelaskan bahwa path coefficients untuk variabel gaya kepemimpinan terhadap kepuasan kerja memiliki indeks sebesar 0,772 dengan nilai $p$ - value $<0,001$ dan nilai effect size for path0,593 sedangkan untuk path coefficientsvariabel stress kerja terhadap kepuasan kerja memiliki indeks sebesar - 


\section{JURNAL ORGANISASI DAN MANAJEMEN}

Issue 2 (Oktober, 2017)

0,012dengan $p$-value 0,465 nilai effect size for path 0,002 . Setelah melakukan uji hipotesis di atas, berikut ini tabel yang merangkum uji hipotesis-hipotesis tersebut :

Tabel 9 Hasil uji hipotesis

\begin{tabular}{|l|l|l|l|l|}
\hline \multicolumn{1}{|c|}{ Hipotesis } & \multicolumn{1}{|c|}{ Independen } & \multicolumn{1}{c|}{ Dependen } & \multicolumn{1}{c|}{$\boldsymbol{p}$-values } & \multicolumn{1}{c|}{ Keputusan } \\
\hline $\mathrm{H}_{1}$ & kepuasan kerja & Gaya Kepemimpinan & $<0,001$ & Diterima \\
\hline $\mathrm{H}_{2}$ & kepuasan kerja & Stres Kerja & $<0,465$ & Ditolak \\
\hline $\mathrm{H}_{3}$ & kepuasan kerja & $\begin{array}{l}\text { Gaya Kepemimpinan } \\
\text { dan Stres Kerja }\end{array}$ & $\begin{array}{l}\text { Nilai } 0,772>\text { dari } \\
\text { nilai }-0,012\end{array}$ & Diterima \\
\hline
\end{tabular}

5.1. Uji hipotesis 1 diterima, artinya variabel gaya kepemimpinan memiliki pengaruh positif dan signifikan terhadap kepuasan kerja pada PT. Utama Duta Harapan. Hal ini ditunjukkan dengan nilai beta $(\beta)$ sebesar 0,772 dengan nilai $p$-value $<0.001$.

5.2. Uji hipotesis 2 ditolak, artinya variabel stress kerja memiliki pengaruh negatif dansignifikan terhadap kepuasan kerja pada PT. Utama Duta Harapan Makassar. Hal ini ditunjukkan dengan nilai beta $(\beta)$ sebesar $-0,012$ dengan nilai $p$-value 0,465 .

5.3. Uji hipotesis 3 diterima, artinya variabel gaya kepemimpinan dominan memiliki pengaruh positif dan signifikan terhadap kepuasan kerja pada PT. Utama Duta Harapan Makassar. Hal ini ditunjukkan dengan variabel gaya kepemimpinan memiliki nilai lebih tinggi yaitu nilai beta $(\beta)$ sebesar 0,772 dengan nilai $p$-value $<0.001$ dibandingkan dengan variabel stress kerja dengan nilai beta $(\beta)$ sebesar $-0,012$ dan nilai $p$-value 0,465 .

\section{Uji besaran pengaruh variabel independen terhadap variabel dependen}

Pengujian besaran pengaruh variabel independen terhadap variabel dependen dapat ditunjukkan pada tabel berikut .

Tabel 10 Ringkasan model (model summary)

\begin{tabular}{|l|c|c|c|}
\hline \multicolumn{1}{|c|}{ Pengukuran } & GP & SK & KP \\
\hline R-squared & & & 0.595 \\
\hline Adj. -squared & & & 0.578 \\
\hline Composite reliab. & 0.919 & 0.958 & 0.885 \\
\hline Cronbach's Alpha & 0.823 & 0.945 & 0.823 \\
\hline Avg. Var. Extrac. & 0.850 & 0.882 & 0.662 \\
\hline
\end{tabular}

Berdasarkan tabel diatas besaran pengaruh nilai $R$-squared pada variabel gaya kepemimpinan dan variabel stres kerja terhadap kepuasan kerja adalah 0,595 $(59,5 \%)$ dan sisanya $40,5 \%$ dipengaruhi oleh variabel lain yang tidak dianalisis dalam penelitian ini.

\section{Interpretasi hasil penelitian}

Penelitian ini membahas pengaruh gaya kepemimpinan terhadap kepuasan kerja, pengaruh stres kerja terhadap kepuasan kerja dan gaya kepemimpinan dominan berpengaruh terhadap kepuasan kerja pada PT. Utama Duta Harapan Makassar. 


\section{JURNAL ORGANISASI DAN MANAJEMEN}

Issue 2 (Oktober, 2017)

\subsection{Pengaruh Gaya Kepemimpinan Terhadap Kepuasan Kerja}

Berdasarkan hasil penelitian, ditemukan bahwa gaya kepemimpinan memiliki pengaruh terhadap kepuasan kerja. Hasil ini sama dengan teori atau temuan dalam penelitian sebelumnya oleh Fitriansyah,R. (2013). memberikan bukti bahwa gaya kepemimpinan berpengaruh positif dan signifikan terhadap kepuasan kerja. Dalam penelitian ini dapat dilihat dari nilai koefisien beta yang menunjukkan bahwa semakin baik gaya kepemimpinan maka semakin tinggi kepuasan kerja yaitu dengan nilai beta $(\beta)$ sebesar 0,772 . Hal ini menunjukkan bahwa variabel gaya kepemimpinan dapat memengaruhi peningkatan kepuasan kerja kearah yang lebih tinggi. Penyebab positif dan signifikannya pengaruh gaya kepemimpinan terhadap kepuasan kerja diakibatkan karena pimpinan selalu memberikan kesempatan kepada karyawan untuk bertanya tentang permasalahan kerja yang memang dianggap benar-benar penting sehingga berdampak pada tingginya kepuasan kerja karyawan dalam menyelesaikan pekerjaan tersebut. Kondisi tersebut didukung dengan pimpinan senantiasa memberikan bimbingan kepada karyawan dalam menyelesaikan pekerjaannya dengan standar yang telah di tetapkan pada PT. Utama Duta Harapan Makassar.

\section{2. $\quad$ Pengaruh Stres Kerja Terhadap Kepuasan Kerja}

Berdasarkan hasil penelitian, ditemukan bahwa Stres kerja memiliki pengaruh terhadap kepuasan kerja. Hasil ini sama dengan teori atau temuan dalam penelitian sebelumnya oleh Dhania, d. R. (2010). Bahwa stress kerja signifikan mempengaruhi kepuasan kerja karyawan. Dalam penelitian ini dapat dilihat dari nilai koefisien beta yang menunjukkan bahwa stress kerja secara signifikan pengaruh terhadap kepuasan kerja yaitu dengan nilai beta $(\beta)$ sebesar $-0,012$. Hal ini menunjukkan bahwa variabel stress kerja tidak mampu memengaruhi kepuasan kerja karyawan. Penyebab negatif dan signifikannya pengaruh stress kerja karyawan diakibatkan karena karyawan sangat cemas dalam menghadapi berbagai tuntutan tugas yang memicu kinerjanya. Kondisi tersebut didukung dengan perusahaan senantiasa memberhentikan karyawannya yang tidak dapat menghadapi tuntutan tugasnya pada PT. Utama Duta Harapan Makassar.

\subsection{Pengaruh Dominan}

Berdasarkan hasil penelitian, ditemukan bahwa pengaruh gaya kepemimpinan lebih dominan dibandingkan pengaruh stres kerja terhadap kepuasan kerja. Hasil tersebut dalam penelitian ini dapat dilihat dari nilai koefisien beta yang ditunjukkan gaya kepemimpinan lebih tinggi yaitu dengan nilai beta $(\beta)$ sebesar 0,772 dan nilai koefisien beta yang ditunjukkan oleh stress kerja yaitu dengan nilai -0,012. Hal ini menunjukkan bahwa variabel gaya kepemimpinan dapat mempengaruhi peningkatan kepuasan kerja kearah yang lebih tinggi dibandingkan variabelkepuasan kerja. Penyebab positif dan signifikannya dominan pengaruh gaya kepemimpinan terhadap kepuasan kerja karyawan diakibatkan karena pimpinan selalu memberikan kesempatan kepada karyawan untuk bertanya tentang permasalahan kerja yang memang dianggap benar-benar penting sehingga berdampak pada tingginya kepuasan kerja karyawan dalam menyelesaikan pekerjaan tersebut.

Kondisi tersebut didukung dengan pimpinan senantiasa memberikan bimbingan kepada karyawan dalam menyelesaikan pekerjaannya dengan standar yang telah di tetapkan pada PT. Utama Duta Harapan Makassar. 


\section{JURNAL ORGANISASI DAN MANAJEMEN}

Issue 2 (Oktober, 2017)

\section{Kesimpulan}

Gaya kepemimpinan dapat memengaruhi peningkatan kepuasan kerja kearah yang lebih tinggi. Penyebab positif dan signifikannya pengaruh gaya kepemimpinan terhadap kepuasan kerja diakibatkan karena pimpinan selalu memberikan kesempatan kepada karyawan untuk bertanya tentang permasalahan kerja yang memang dianggap benar-benar penting sehingga berdampak pada tingginya kepuasan kerjakaryawan dalam menyelesaikan pekerjaan Stress kerja yang rendah tidak mampu memengaruhi peningkatan kepuasan kerja. Kondisi tersebut diakibatkan karena karyawan sangat cemas dalam menghadapi berbagai tuntutan tugas yang memicu kinerjanya dan perusahaan senantiasa memberhentikan karyawannya yang tidak dapat menghadapi tuntutan tugasnya Gaya kepemimpinan dominan berpengaruh terhadap kepuasan kerja. Kondisi tersebut disebabkan karena pimpinan selalu memberikan kesempatan kepada karyawan untuk bertanya tentang permasalahan kerja yang memang dianggap benar-benar penting sehingga berdampak padatingginya kepuasan kerja karyawan.

Penelitan ini merekomendasikan kepada peneliti selanjutnya untuk menambah beberapa variabel independen lainnya agar variabel tersebut mampu menjelaskan variabel dependen lebih besar dari penelitian sebelumnya sehingga mendapatkan hasil yang lebih akurat. Dalam hal waktu, hendaklah peneliti selanjutnya dapat memiliki waktu yang cukup untuk melakukan penelitian sehingga bisa mencapai hasil yang maksimal. Kepada PT. Utama Duta Harapan untuk lebih meningkatkan dan tetap menjaga kepemimpinannya agar lebih baik sehingga karyawan tetap merasa puas dalam bekerja, serta dapat memperbaiki system kerja yang baik agar stress karyawan dalam bekerja dapat berkurang dan teratasi.

\section{DAFTAR PUSTAKA}

Afrizal, P. R. (2014). Pengaruh konflik kerja dan stress kerja terhadap kepuasan kerja (studi pada karyawan PT. TASPEN (PERSERO) cabang Malang).Jurnal Administrasi Bisnis, 8(1).

Brahmasari, I. A., \& Suprayetno, A. (2009). Pengaruh Motivasi Kerja, Kepemimpinan dan Budaya Organisasi Terhadap Kepuasan Kerja Karyawan serta Dampaknya pada Kinerja Perusahaan (Studi kasus pada PT. Pei Hai International Wiratama Indonesia). Jurnal Manajemen dan Kewirausahaan, 10(2), $p p-124$.

Dewi, N. K. N. C., \&Subudi, I. Pengaruh Kepemimpinan Transformasional Terhadap Kepuasan Kerja dan Turnover Intention Pada CV. Gita Karya Persada Denpasar. E-Jurnal Manajemen Universitas Udayana, 4(12).

Faqihudin, M., \& Gunistiyo, M. S. (2009). Pengaruh Stres Kerja Terhadap Kepuasan Kerja Dan Intensi Meninggalkan Organisasi Pada Bank-Bank Milik Negara Di Kota Tegal. Sosekhum, 5(7).

Fitriansyah, R.(2013). Pengaruh Gaya Kepemimpinan Transformasional Dan Transaksional Terhadap Kepuasan KerjaKaryawan (Studi Pada Agen Financial Consultant PT. Axa Financial Indonesia Sales Office Malang).Jurnal Administrasi Bisnis, 4(2).

Ghozali, Imam. (2013). Aplikasi Analisis Multivariate Dengan Program SPSS (Edisi ketujuh). Semarang :UniversitasDiponegoro 
Issue 2 (Oktober, 2017)

Noor, N. N., Rahardjo, K., \& Ruhana, I. (2016). Pengaruh Stres Kerja Dan Kepuasan Kerja Terhadap Kinerja Karyawan (Studi Pada Karyawan PT Jasa Raharja (Persero) Cabang Jawa Timur di Surabaya). Jurnal Administrasi Bisnis, 31(1), 9-15.

Potale, R., \& Uhing, Y. (2015). Pengaruh Kompensasi dan Stres Kerja Terhadap Kepuasan Kerja Karyawan Pada PT. Bank Sulut Cabang Utama Manado. Jurnal Riset Ekonomi, Manajemen, Bisnis Dan Akuntansi, 3(1).

Pradifta, N. B. H., \& Sudibia, G. A. Pengaruh Kepemimpinan Transformasional dan Kepuasan Kerja Terhadap Komitmen Organisasional (Studi Pada Aerowisata Sanur Beach Hotel). E-Jurnal Manajemen Universitas Udayana, 3(9).

Simanungkalit, Y. M. V., \& Setyaningsih, E. (2013). Pengaruh Gaya KepemimpinanTerhadap Kepuasan Kerja Karyawan Pada PT. Lion Mentari Airlines.UG Jurnal, 7(6).

Sjahruddin, H. 1 E-Library STIE YPBUP Bongaya 2016.

Sjahruddin, H., Vivi, M., \& Ahmad, A. (2014).Pengaruh Stres dan Lingkungan Kerja Non Fisik Terhadap Kinerja Karyawan Pada PT. Bumi Jasa Utama (Kallatransport) Makassar. E-Library STIE YPBUP Bongaya.

Tunjungsari, P. (2011). Pengaruh Stress Kerja Terhadap Kepuasan Kerja Karyawan Pada Kantor Pusat PT. Pos Indonesia (Persero) Bandung. Jurnal Universitas Komputer Indonesia, 1(1), 1 